\title{
TEACHING ENVIRONMENTAL HEALTH IN THE MEDICAL ACADEMY OF LATVIA/RIGA STRADIN̦Š UNIVERSITY
}

While teaching future health care specialists, there are four important basic directions in medicine: preventive measures, diagnostics, therapy and rehabilitation. Students must be taught not only diagnosing and healing different diseases and health disturbances and, how to restore normal functioning of the human body, but they must also have knowledge about how to divert and reduce risks of health disturbances.

For a long time fundamental hygiene was the only subject of preventive medicine taught at the Department of hygiene of our Academy. In the eighties of last century the Faculty of the aim preventive medicine was founded with to prepare doctors for preventive medicine. Until this time such kind of specialists were prepared in hygienic institutes in the former USSR far from Latvia. Therefore, we needed to extend teaching here in Latvia because students of the Faculty of preventive medicine must have deep knowledge in every branch of hygiene.

The same time we paid attention to the fact that the significance of mutual influence of hygiene and human ecology grows side by side with progressive biosphere pollution. Today there is no alternative to nature protection - we have to protect our environment from ourselves and because of ourselves. Human ecology has stopped to be a biological science and has a medically biological and socially hygienic meaning. Consequences of interference in environment made human ecology into a great science with multiple scientific directions and basics - to keep environment and human health in harmony, which is determined by social aspects of our society.

Human ecology and hygiene study the antropo-ecological system "man-environment" with man, society and their health in the center, paying attention to the influence of all environmental factors on living processes. These two branches of science have common fundamentals - goals into solution of the global ecological crisis.

Scientific-technical development expands ecological area of environmental factors and disbalances human biological characteristics with its abilities timely to adapt new factors of the technogenic environment, especially chemical ones. The rate 
and unexpectability of ecological changes in some periods (ages) of life overtakes limited speed and ability of adaptation of human body.

Variable circumstances of disease etiology make us create knew scientific basis how to explain the mutual reason - consequence dependence of "environmenthealth-disease". In this situation ecological appraisal of environmental factors, its influence on human body and also methodical approaches of preventive measures will cross, so teaching the influence of environmental factors on human life processes is conceptually one whole ecological and hygienical matter.

Human ecology studies have a great importance in preparing health care specialists (doctors, dentists, nurses, rehabitologists, pharmacists, and hygienists). For our department it took subject changes, renovation of status of department and expanded ecology teaching. Three educational books $[1,2,3]$ were published with deeply expanded review of ecological issues. Content and form integration teaching hygiene and ecology promoted high quality of future health care specialists preparing in both directions: preventive and ecological.

In Latvia's the system of higher education, hygiene and human ecology were two subjects without a special study program, teaching methods and educational material. In spring 1998, students graduated the Faculty of preventive medicine for the last time [4]. According to rules of Ministry Wellfare Latvia, those 53 preventive medicine doctors may work as laboratory doctors, occupational disease doctors, epidemiologists, occupational health doctors (additional speciality).

During the same spring students from the Faculty of public health started a new subject - environmental health (including work environment). Environmental health is a branch of environmental science, which develops theoretical and practical basics for studying, identifying, evaluating and controlling of favorable and adverse environmental factors and how to reduce or prevent their possibly detrimental effects on human health. The most important health saving precondition is to keep clean life and work environment, not only to treat health disturbances made by polluted environment's adverse factors.

Environmental health is the main subject for environmental health specialists preparing in Faculty of public health. The principle of teaching environmental health is to clear up the relationships of man and of medically biological and socially hygienic factors of environment in system "environment-man-society". The goal is to introduce students with different environmental components (air, water, work); to teach how to value a variety of environmental conditions, their influence on living organism; to teach how to use knowledge in their future work. Environmental health as an educational subject has to be explained using a structurally systematic approach with objective, multilevel and all-round appraisal of environmental factors, human and society health.

In the late nineties in our Department new study programs for all faculties of the Academy were developed to promote high educational quality. Developing educational programs we used foreign materials and also ours from different branches of 
hygiene (fundamental, occupational, nutrition, children and teenagers), human ecology and Preventive medicine. For developing environmental health educational program for students from Faculty of public health we mostly used Scandinavian experience.

So when developing programs we regarded specifics of future professions. Rehabitologists, dentists, pharmacists and nurses study a short, one-semester program with special attention to clearing up and evaluating work environment risks. Students from the Faculty of medicine study an expanded 2 semesters program. The largest program was made for students from Faculty of public health and they have to spend 4 years (seven semesters) studying environmental health. In the first and second study year they get knowledge about air its physical, chemical, biological qualities, its significance, influence, pollution and protective measures. Second study year they spend studying water and its ecological, hygienic, physiological, economical, epidemiological role in human life. They spend the third study year studying such subjects: food as an environmental component; soil as an environmental component; planning and furnishing of living settlements; living; social and medical institutions, hygiene of children and teenagers. The forth study year students from the Faculty of public health study a large environment health course, including themes about occupational hazards, physiology, psychology, law, about ergonomically related problems, about occupational diseases and diseases related to work environment, about actions of occupational health service and about occupational epidemiology. All programs correspond to international standards and are approved in our high school.

Since the recovery of independence remarkable changes have taken place in the Department of hygiene which was renamed, as the Department of occupational and environmental medicine. The main profiling medicine subject is environmental health. In the Department lecturers with a great practical and research experience, who lead studies in the Faculties of medicine, nursing, pharmacy, rehabilitation, stomatology, public health do work.

During the last three years we have written several educational books: about the air in Latvian [5] and in English [6], about water in English [7], about food in Latvian [8] and in English [9], about children and teenager hygiene in Latvian [10], about occupational hazards in English [11], about health problems in living settlements in Latvian [12], about methodical instructions for practical work of environmental health in English[13]. New educational material is being developed all the time. Study programs are improved every year with additional material: new research results, theoretical conclusions and law.

\section{Summary}

Nowadays health care problems become actual and very great attention must be paid to saving and accommodating human health, not only how to divert health disturbances, how to diagnose fast and qualitatively, how to treat effectively. Preparing health care specialists of different branches the most important is 
teaching preventive medicine. The main subject is environmental health. Every faculty has developed new educational programs, to improve studies with fundamental hygiene and human ecology experience from the previous years supplying it with the newest conclusions in this sphere. Lecturers from the department have written several educational books, methodical instructions and supplied study programs with other materials (Internet, biomedical data base, open book foundation).

\section{References}

1. Higiēna / Prof. Z. Lindbergas red. - Rīga: Zvaigzne, 1991. - 368 lpp.

2. Eglīte M. Cilvēka ekolog̀ija. - Rīga: AML Darba medicīnas institūts, 1993. - 56 lpp.

3. Eglīte M. Human Ecology. - Rīga: AML, Department of Human Ecology and Occupational Medicine, 1994. - 122 p.

4. AML Medicīnas fakultātes Profilaktiskâs medicinas noda|as valsts eksāmenu komisijas sēdes protokoli par ārsta grāda piešḳiršanu. - AML/RSU Arhīva materiāli, 1998.

5. Dundurs $J$. Vides veselība: Gaiss. - Rĩga: $A M L / R S U$ Darba un vides veselības institūts, 2000. $-48 \mathrm{lpp}$.

6. Eglite M., Jekabsone I. Environmental Medicine: Part I: Air. - Riga: AML, Institute of Occupational and Environmental Health, 1998. -38 p.

7. Eglite M., Avota M., Dundurs J., Jekabsone I. Environmental Medicine: part II: Water - Riga: $A M L$, Institute of Occupational and Environmental Health, 1998. - $27 \mathrm{p}$.

8. Aulika $B$. Uztura higiêna. - Rīga: $A M L / R S U$ Darba un vides veselības institūts, 2001. - 124 lpp.

9. Dundurs J. Environmental Health: Food. - Riga: AML/RSU, Institute of Occupational and Environmental Health, 1998. $-51 \mathrm{p}$.

10. Aulika $B$. Bērnu un pusaudžu higiēna. - Rĩga: $A M L / R S U$ Darba un vides veselības institūts, 2000, $-87 \mathrm{lpp}$.

11. Dundurs J. Occupational Health Hazards. - Riga: AML/RSU, Institute of Occupational and Environmental Health, 1998. - 84 p.

12. Dundurs $J$. Vides veselība: Apdzīvotas vietas. - Rīga: $A M L / R S U$ Darba un vides veselïbas institūts, 2000. $-88 \mathrm{lpp}$.

13. Dundurs J. Methodic Directions on the Practical Works of Environmental Health. Riga: $A M L / R S U$, Institute of Occupational and Environmental Health, 1998. - 72 p.

\section{Biruta Aulika \\ Jānis Dundurs}

Department of Occupational and Environmental Medicine

Riga Stradin̄š University

Dzirciema 16, Riga, LV-1007

Latvia 